\title{
Pengaruh "Brand Name", "Perceived Quality", Harga terhadap Keputusan Pembelian Bahan Bakar Minyak jenis Super, Studi Kausalitas pada Pengguna Motor Produksi Masal di Shell BSD 1 Jalan Pahlawan Seribu
}

\author{
Angelia Inggriani ${ }^{1}$ \\ Suhendar Janamarta ${ }^{2}$ \\ Manajemen, Universitas Buddhi Dharma, Indonesia, Banten
}

\begin{abstract}
ABSTRAK
Suatu produk tentu tidak lepas dari yang namanya merek. Banyak masyarakat lebih sering menyebutkan mereknya daripada menyebutkan produk itu sendiri. Seiring berjalannya waktu dalam membeli produk, selain mereknya, tentu masyarakat juga memperhatikan kualitas dari produk tersebut karena dalam konsumsi bahan bakar minyak (BBM) berkualitas tinggi, semakin melaju seiring kesadaran konsumen terhadap komoditas tersebut yang kian meningkat. Dalam membeli produk tidak hanya dilihat dari segi kualitas atau merek semata. Tetapi dilihat juga dari segi harga. Harga juga bisa menjadi keputusan membeli untuk masyarakat membeli suatu produk.

Tujuannya adalah melihat pengendara motor produksi masal yang secara umum adalah kelas ekonomi menengah kebawah yang memperhitungkan biaya operasional yang menggunakan pengeluaran seminim mungkin untuk menekan pengeluaran.

Penelitian ini adalah penelitian kuantitatif dengan metode kuisioner dan jenis penelitiannya adalah eksplanasi kausalitas pada pengguna motor produksi masal yang memakai bahan bakar shell jenis super.

Dari 95 responden, mayoritas responden yang menjawab kuisioner berjenis kelamin pria, berumur 20 - 29 tahun, berprofesi pegawai swasta, berpendidikan terakhir SMA / SMK dan pengeluaran biaya hidup rata - rata per bulan sekitar 1 juta - 2 juta. Dari hasil penelitian yang dilakukan, terbentuk persamaan regresi linear yaitu : $\mathrm{Y}=-0,70+0,223 \mathrm{X} 1+0,335 \mathrm{X} 2+0,401 \mathrm{X} 3$. Dan berdasarkan hasil penelitian, didapat $\mathrm{F}$ hitung yaitu sebesar 32,834 lebih besar dari $\mathrm{F}$ tabel yaitu sebesar 2,70 dengan tingkat signifikan dibawah 0,05 yaitu sebesar 0,000.
\end{abstract}

Kata Kunci : Shell, Super, Brand Name, Perceived Quality, Harga 


\begin{abstract}
A product certainly cannot be separated from the brand name. Many people more often mention the brand of the product itself. As time goes by in buying products, including the brand, of course people are also paying attention to the quality of the product because in providing fuel oil of high quality, increasingly drove, including, consumers, and others. And in purchasing the product not only in terms of quality or brand alone. In terms of price, price can also be a purchase for the product community.

Seeing the massively mass-produced motorist is an economic class that allows operational costs that use minimal use to burst.

This research is a quantitative research with questionnaire method and the type of research is the explanation of causality in mass motor users using super shell fuel.

Of the 95 respondents, the respondents who answered were men, aged 20-29 years old, private employment profession, last high school / vocational school and spent an average cost per month about 1 million - 2 million. From the results of research conducted, conducted linear regression analysis that is: $Y=-0.70+0.223 X 1+0.335 X 2+0.401 X 3$. And based on the results of research, obtained Fhitung is equal to 32.834 greater than $F$ table that is equal to 2.70 with a significant level below 0.05 that is 0.000 .
\end{abstract}

Key Words : Shell, Super, Brand Name, Perceived Quality, Price

\title{
PENDAHULUAN
}

Suatu produk tentu tidak lepas dari yang namanya merek. Banyak masyarakat lebih sering menyebutkan mereknya daripada menyebutkan produk itu sendiri. Menanamkan nama merek di dalam benak masyarakat adalah hal yang tidak mudah, karena mungkin sudah ada pesaingnya terlebih dahulu, atau mungkin nama merek tersebut sulit untuk di ingat. Apalagi untuk pendatang baru, membuat merek tersebut teringat dibenak masyarakat adalah sebuah tantangan. Nama merek (brand name) merupakan indikator inti bagi sebuah merek yang merupakan landasan bagi upaya komunikasi dan penciptaan kesadaran. Nama merek yang efektif juga dapat dimanfaatkan untuk menciptakan pesan pertama terhadap positioning khusus. Seiring berjalannya waktu dalam membeli produk, tidak hanya memerhatikan mereknya. Tentu masyarakat juga memperhatikan kualitas dari produk tersebut karena dalam konsumsi bahan bakar minyak (BBM) berkualitas tinggi, semakin melaju seiring kesadaran konsumen terhadap komoditas tersebut yang kian meningkat. Kualitas yang dirasakan konsumen dari sebuah merek sesuai dengan proses persepsi mereka yang terlibat dalam proses pengambilan keputusan. Kualitas yang dirasakan tinggi terjadi ketika konsumen mengenali diferensiasi dan keunggulan merek relatif terhadap merek pesaing. Ini akan mempengaruhi keputusan pembelian mereka dan akan mendorong mereka untuk memilih merek daripada merek pesaing. Dewasa ini, dalam membeli produk tidak hanya dilihat dari segi kualitas atau merek semata. Tetapi dilihat juga dari segi harga. Harga juga bisa menjadi keputusan membeli untuk masyarakat membeli suatu produk. Tetapi harga tidak menjadi penentu utama dalam keputusan membeli produk. Harga merupakan sejumlah nilai yang konsumen tukarkan untuk sejumlah manfaat dengan memiliki atau menggunakan suatu barang atau jasa. 
Masyarakat tentunya sudah identik dengan tempat pengisian Bahan Bakar Minyak di Pertamina. Tetapi sejak dibukanya pasar bebas ASEAN pada tahun 2010, masuklah perusahaan Shell ke Indonesia. Masyarakat mulai mencoba beralih ke bahan bakar Shell. Penelitian ini mengambil Shell sebagai objek penelitian. Alasannya adalah karena melihat pengendara motor produksi masal yang secara umum adalah kelas ekonomi menengah kebawah yang memperhitungkan biaya operasional yang menggunakan pengeluaran seminim mungkin untuk menekan pengeluaran. Peneliti pun akhirnya memutuskan untuk melakukan pre research untuk menyelidiki fakta dilapangan. Peneliti melakukan wawancara sedikit dengan petugas SPBU Shell dan SPBU Pertamina serta melihat keadaan dilapangan secara langsung. Sedikit pertanyaan dan secara spontan pun dilontarkan kepada masing masing petugas, dan didapatkan sejumlah fakta. Peneliti juga melihat pengendara motor produksi masal yang secara umum adalah kelas ekonomi menengah kebawah yang memperhitungkan biaya operasional yang menggunakan pengeluaran seminim mungkin untuk menekan pengeluaran, mengisi bahan bakar di SPBU Shell. Walaupun harga bensin Shell jauh lebih mahal dibandingkan Pertamina. Penelitian ini menarik untuk dilakukan dimana bertujuan untuk melihat faktor mana yang lebih berpengaruh terhadap Keputusan Pembelian bahan bakar minyak Shell BSD 1 Jalan Pahlawan Seribu.

\section{LANDASAN TEORI \\ Brand Name}

Menurut (Elliot, Rundle-Thiele, dan Waller 2012,232) memberikan definisi sebagai berikut: "A Brand Name is a part of a brand that can be spoken and can include words, letters and number.". Menurut (Borrington dan Stimpson 2006,289) memberikan definisi sebagai berikut: "Brand Name is the unique name of a product that distinguishes it from other brands". Menurut (Solomon 2015, 232) memberikan definisi sebagai berikut: "Brand name is the first and most critical step in brand development". Dari beberapa definisi diatas mengenai brand name, dapat ditarik kesimpulan bahwa Brand Name adalah bagian dari merek yang mudah di ingat serta menjadi pembeda antara merek lain dalam pengembangan suatu merek.

\section{Perceived Quality}

Menurut (Ma'Arif 2008, 126) memberikan definisi sebagai berikut: "Perceived Quality refers to customer's perception of the overall quality or superiority of a product or service in comparison with other products.". Menurut Zeithaml (dalam Wankhade dan Dabade 2010, 27) memberikan definisi sebagai berikut: "Perceived Quality is the consumer's judgement about an entity's overall excellence or superiority.". Menurut ( Aaker 2014, 48) memberikan definisi sebagai berikut: "Perceived Quality is a key consideration in nearly every choice context.". Dari beberapa definisi diatas mengenai Perceived Quality, dapat ditarik kesimpulan bahwa Perceived Quality adalah persepsi dan pertimbangan konsumen dalam menentukan kualitas yang dipilihnya.

\section{Harga}

Menurut (Elliot, Rundle-Thiele, dan Waller 2012, 23) memberikan definisi sebagai berikut: "Price is the amount of money a business demands in exchange for its offerings.". Menurut (Dr. Badrudin,M.Ag 2013, 26) memberikan definisi sebagai berikut : Harga 
adalah kompensasi yang harus dilakukan untuk mendapatkan sejumlah barang dan jasa. Menurut (Ma' Arif 2008, 138) memberikan definisi sebagai berikut: "Price is an observable component of the product that results in consumer purchasing it or not.". Dari beberapa definisi diatas mengenai harga, dapat ditarik kesimpulan bahwa harga adalah sejumlah nilai yang tertulis dan keputusan kepada konsumen untuk pembelian suatu barang atau jasa.

\section{Keputusan Pembelian}

Menurut (Kottler \& Keller 2016, 198) memberikan definisi sebagai berikut: "Purchase Decision is in the evaluation stage when the customer forms preferences among the brands in the choice set and may also form an intention to buy the most preferred brand.". Menurut Lyonski (dalam Evans et al 2009, 2014) memberikan definisi sebagai berikut: "Decision making is defined as a mental orientation characterizing a consumer's approach to making shopping choices". Menurut (Elliot, Rundle-Thiele, dan Waller 2012, 135) memberikan definisi sebagai berikut : "The process of need / want recognition, information search, evaluation of options, purchase and post-purchase evaluation that are common to most consumer buying decisions.". Dari beberapa definisi diatas mengenai Keputusan Pembelian, dapat ditarik kesimpulan bahwa Keputusan Pembelian adalah evaluasi yang dilakukan oleh konsumen untuk menentukan apakah melakukan pembelian atau tidak terhadap suatu produk.

\section{METODE PENELITIAN}

\section{Teknik Pengumpulan Data}

Teknik pengumpulan data ini menggunakan cara menyebarkan angket kertas di SPBU Shell BSD 1 Jalan Pahlawan Seribu dengan memberikan angket kertas kepada pengemudi. Pengumpulan dilakukan sampai memenuhi target sampel.

\section{Populasi dan Sampel}

Menurut ( Sugiyono 2017, 136) Populasi adalah wilayah generalisasi yang terdiri atas: obyek / subyek yang mempunyai kuantitas dan karaterisitik tertentu yang ditetapkan oleh peneliti untuk dipelajari dan kemudian ditarik kesimpulannya. Responden merupakan pengguna motor produksi masal yang menggunakan bahan bakar minyak jenis super di Shell BSD 1 Jalan Pahlawan Seribu.

Menurut ( Sugiyono 2017, 137) Sampel adalah sebagian dari jumlah karakteristik yang dimiliki oleh populasi tersebut, ataupun bagian kecil dari anggota yang di ambil menurut prosedur tertentu sehingga dapat mewakili populasinya. Jika populasi besar, peneliti tidak mungkin mempelajari seluruh yang ada di populasi, hal seperti ini dikarenakan adanya keterbatasan biaya, tenaga dan waktu. Oleh sebab itu peneliti dapat memakai sampel yang di ambil dari populasi tersebut harus akurat dan representative atau dapat mewakili. Menurut (Sugiyono 2011, 81) terdapat beberapa ukuran sampel, yaitu sebagai berikut:

a. Ukuran sampel yang layak digunakan dalam penelitian adalah antara 30 - 100

b. Bila dalam penelitian melakukan Analisa dengan menggunakan multiple regression, maka sampel minimal 10 kali jumlah variabel yang diteliti. Dalam penelitian ini, peneliti menggunakan variabel Brand Name, Perceived Quality, Harga dan Keputusan Pembelian, sehingga dapat dirumuskan yaitu setiap variabel akan dikalikan 10 dan rumus yang digunakan yaitu : Jumlah Minimum Sampel $=4 \times 10=40$ 
Hal ini dapat membantu peneliti dalam meminimalkan jumlah sampel. Namun tidak merusak hasil penelitian. Dan peneliti mengambil sampel berjumlah 95 sebagai bahan penelitian yang akan membantu pemecahan masalah.

\section{Jenis Data}

Penelitian dilakukan dengan menggunakan kuisioner dan wawancara dalam pengumpulan datanya, maka sumber datanya berasal dari responden yang menjawab. Didapat dari penyebaran angket kertas dan di SPBU Shell BSD 1 Jalan Pahlawan Seribu.

\section{Sumber Data}

Dalam Penelitian ini, untuk mendapatkan data yang relevan digunakan sumber data primer. Data primer adalah data yang diperoleh langsung dari sumber asli. Data primer dikumpulkan untuk menjawab pertanyaan penelitian.

\section{Metode Analisis}

\section{Uji Validitas}

Menurut ( Ghozali 2016, 52 ) Uji Validitas digunakan untuk mengukur sah atau valid tidaknya suatu kuisioner. Suatu kuisioner dikatakan valid jika pertanyan pada kuisioner mampu mengungkapkan sesuatu yang akan diukur oleh kuisioner tersebut. Mengukur validitas dilakukan dengan tiga cara :

i. Melakukan korelasi antar skor butir pertanyaan dengan total skor konstruk atau variabel.

ii. Uji Validitas dapat juga dilakukan dengan melakukan korelasi bivariate antara masing - masing skor indikator dengan total skor konstruk.

iii. Uji dengan Confirmation Factor Analysis (CFA)

\section{Uji Reliabilitas}

Menurut ( Ghozali 2016, 47 ) Uji Reliabilitas adalah alat untuk mengukur suatu kuisioner yang merupakan indikator dari variabel atau konstruk. Pengukuran reliabilitas dapat dilakukan dengan dua cara, yaitu : repeat measure / pengukuran ulang dan one shot / pengukuran sekali saja. SPSS memberikan fasilitas untuk mengukur reliabilitas dengan uji statistik Cronbach Alpha $(\alpha)$. Suatu konstruk atau variabel dikatakan reliabel jika memberikan nilai Cronbach Alpha $(\alpha)>0.70$

\section{Uji Autokorelasi}

Menurut ( Ghozali 2016, 107) Uji Autokorelasi bertujuan menguji apakah dalam model regresi linear ada korelasi antara kesalahan pengganggu pada periode $t-1$ ( sebelumnya). Mendeteksi autokorelasi dapat dilihat dari Durbin - Watson (DW) dan disesuaikan dengan tabel pengambilan keputusan autokorelasi.

\section{Uji Heteroskedastisitas}

Menurut ( Ghozali 2016, 134) Uji Heteroskedastisitas bertujuan menguji apakah dalam model regresi terjadi ketidaksamaan variance dari residual satu pengamatan ke pengamatan yang lain. Jika variance dari residual satu pengamatan ke pengamatan lain tetap, maka disebut Homoskedastisitas dan jika berbeda disebut Heteroskedastisitas. Salah satu cara untuk menguji heteroskedastistas adalah dengan melihat grafik plot antara nilai prediksi variabel terikat (dependen ) yaitu ZPRED dengan residualnya SRESID. Jika ada pola tertentu seperti titik - titik yang ada membentuk pola tertentu yang teratur ( bergelombang, melebar, kemudian menyempit ), maka mengindikasikan telah terjadi heteroskedastistas. Jika tidak ada 
pola yang jelas, serta titik - titik menyebar diatas dan dibawah angka nol pada sumbu Y, maka tidak terjadi heteroskedastisitas.

\section{Uji Normalitas}

Menurut ( Ghozali 2016, 154 ) Uji Normalitas bertujuan untuk menguji apakah dalam model regresi, variabel pengganggu atau residual memiliki distribusi normal. Pada uji normalitas dapat dilihat pada grafik P - P Plot, yang dimana prinsipnya normalitas dapat dideteksi dengan melihat penyebaran data ( titik ) pada sumbu diagonal dari grafik. Bila menyebar disekitar garis diagonal dan mengikuti arah garis diagonal, maka model regresi memenuhi asumsi normalitas. Bila menyebar jauh dari diagonal dan / atau tidak mengikuti arah garis diagonal, maka model regresi tidak memenuhi asumsi normalitas.

\section{Uji Multikolinieritas}

Menurut ( Ghozali 2016, 103 ) Uji Multikolinieritas bertujuan untuk menguji apakah suatu model regresi ditemukan adanya korelasi antar variabel bebas. Untuk mengetahui adanya multikolinieritas atau tidak, dilihat dari nilai tolerance dan VIF ( Variance Inflation Factor). Nilai yang menunjukkan adanya multikolinieritas adalah nilai tolerance $\leq 0,10$ atau nilai VIF $\geq 10$.

\section{Uji Koefisien Determinasi}

Menurut ( Ghozali 2016, 95) Uji Koefisien Determinasi $\left(\mathrm{R}^{2}\right)$ mengukur seberapa jauh kemampuan model dalam menerangkan variasi variabel dependen. Nilai koefisien determinasi adalah antara nol dan satu. Maka jika $\mathrm{R}^{2}$ yang kecil, berarti kemampuan variabel - variabel independen dalam menjelaskan variasi variabel dependen amat terbatas.

\section{Uji Korelasi}

Menurut ( Ghozali 2016, 93 ) Uji Korelasi bertujuan untuk mengukur kekuatan asosiasi linear antara dua variabel. Korelasi tidak menunjukkan hubungan fungsional atau dengan lain analisis korelasi tidak membedakan antara variabel dependen dengan variabel independen.

\section{Uji Statistik F}

Menurut ( Ghozali 2016, 96) Uji F menguji hipotesis bahwa b1, b2, dan b3 secara simultan sama dengan nol. Cara perhitungan adalah dengan membandingkan nilai $\mathrm{F}$ hasil perhitungan dengan nilai $\mathrm{F}$ menurut tabel. Jika $\mathrm{F}$ dihitung lebih besar dari $\mathrm{F}$ tabel maka Ho ditolak dan Ha diterima.

\section{Uji Statistik t}

Menurut ( Ghozali 2016, 97 ) Uji statistik t pada dasarnya menunjukkan seberapa jauh pengaruh satu variabel independen secara individual dalam menerangkan variasi variabel dependen. Cara perhitungan adalah dengan membandingkan nilai statistik $\mathrm{t}$ dengan nilai $\mathrm{t}$ menurut tabel. Apabila nilai statistik $\mathrm{t}$ hasil perhitungan lebih tinggi dibandingkan nilai $\mathrm{t}$ tabel, maka Ha diterima.

\section{Analisis Regresi Berganda}

Metode yang digunakan untuk menganalisis data adalah metode Regresi Linier Berganda. Rumusnya adalah :

$Y=\beta 0+\beta 1 . X 1+\beta 2 . X 2+\beta 3 . X 3+\varepsilon$

Keterangan:

$Y=$ Keputusan Pembelian

$\beta 0=$ Konstanta 
$\beta 1=$ Brand Name

$\beta 2=$ Perceived Quality

$\beta 3=$ Harga

$\varepsilon=$ error

Menurut ( Gudono 2016, 137 ) dimana Y ( Keputusan Pembelian) adalah variabel dependen yang nilainya dipengaruhi oleh variabel X1 (Brand Name ), X2 ( Perceived Quality), X3 ( Harga ) yang merupakan variabel independen. Perhitungan analisis regresi berganda akan menggunakan software SPSS 23,0

\section{HASIL DAN PEMBAHASAN}

Uji Reliabilitas Brand Name

\section{Reliability Statistics}

\begin{tabular}{|r|r|}
\hline $\begin{array}{c}\text { Cronbach's } \\
\text { Alpha }\end{array}$ & $\begin{array}{c}\text { N of } \\
\text { Items }\end{array}$ \\
\hline, 786 & 10 \\
\hline
\end{tabular}

Sumber: Pengolahan Data SPSS 23,0

Berdasarkan hasil pengolahan data dengan SPSS 23, dapat disimpulkan bahwa hasil uji reliabilitas dari variabel brand name (X1), dinyatakan reliabel karena nilai cronbach alpha $0,786>0,70$ dan layak menjadi indikator.

Menurut (Ghozali 2016, 52 ) Uji Validitas dilakukan dengan cara membandingkan nilai $r$ hitung dengan $r$ tabel untuk degree of freedom $(\mathrm{df})=\mathrm{n}-2$ dimana $\mathrm{n}$ adalah jumlah sampel dan titik signifikansi adalah 5\%. Melalui cronbach's alpha pada kolom Correlated Item - Total Correlation, dapat dilihat untuk menguji valid atau tidaknya suatu indikator.

\section{Uji Validitas Brand Name (X1)}

Item-Total Statistics

\begin{tabular}{|l|r|r|r|r|}
\hline & $\begin{array}{c}\text { Scale Mean if } \\
\text { Item Deleted }\end{array}$ & $\begin{array}{c}\text { Scale } \\
\text { Variance if } \\
\text { Item Deleted }\end{array}$ & $\begin{array}{c}\text { Corrected } \\
\text { Item-Total } \\
\text { Correlation }\end{array}$ & $\begin{array}{c}\text { Cronbach's } \\
\text { Alpha if Item } \\
\text { Deleted }\end{array}$ \\
\hline bn1 & 36,6632 & 22,736 &, 465 &, 771 \\
bn2 & 36,6316 & 23,405 &, 295 &, 785 \\
bn3 & 36,5789 & 21,714 &, 587 &, 758 \\
bn4 & 36,8526 & 21,042 &, 556 &, 757 \\
bn5 & 36,8947 & 20,074 &, 482 &, 766 \\
bn6 & 37,4632 & 20,017 &, 398 &, 783 \\
bn7 & 36,9684 & 20,542 &, 533 &, 758 \\
bn8 & 36,7684 & 21,116 &, 406 &, 775 \\
bn9 & 36,7895 & 20,891 &, 528 &, 759 \\
bn10 & 36,7263 & 21,456 &, 449 &, 769 \\
\hline
\end{tabular}

Sumber: Pengolahan Data SPSS 23,0 
Berdasarkan hasil uji validitas, variabel brand name (X1), dapat dikatakan bahwa seluruh item valid dengan nilai $\mathrm{r}$ hitung positif dan lebih besar dari nilai $\mathrm{r}$ tabel menurut (Sugiyono,2017) $=0.1698$. dengan titik signifikansi 0,05.

\section{Uji Reliabilitas Perceived Quality (X2)}

\section{Reliability Statistics}

\begin{tabular}{|r|r|}
\hline $\begin{array}{c}\text { Cronbach's } \\
\text { Alpha }\end{array}$ & $\begin{array}{c}\text { N of } \\
\text { Items }\end{array}$ \\
\hline, 757 & 10 \\
\hline
\end{tabular}

Sumber: Pengolahan Data SPSS 23,0

Berdasarkan hasil pengolahan data dengan SPSS 23, dapat disimpulkan bahwa hasil uji reliabilitas dari variabel perceived quality (X2), dinyatakan reliabel karena nilai cronbach alpha 0,757 > 0,70 dan layak menjadi indikator.

\section{Uji Validitas Perceived Quality (X2)}

\section{Item-Total Statistics}

\begin{tabular}{|l|r|r|r|r|}
\hline & $\begin{array}{c}\text { Scale Mean if } \\
\text { Item Deleted }\end{array}$ & $\begin{array}{c}\text { Scale } \\
\text { Variance if } \\
\text { Item Deleted }\end{array}$ & $\begin{array}{c}\text { Corrected } \\
\text { Item-Total } \\
\text { Correlation }\end{array}$ & $\begin{array}{c}\text { Cronbach's } \\
\text { Alpha if Item } \\
\text { Deleted }\end{array}$ \\
\hline pq1 & 37,1474 & 18,127 &, 541 &, 722 \\
pq2 & 37,3158 & 18,389 &, 470 &, 731 \\
pq3 & 37,7789 & 16,876 &, 409 &, 744 \\
pq4 & 37,7579 & 18,909 &, 203 &, 778 \\
pq5 & 37,0316 & 18,818 &, 545 &, 727 \\
pq6 & 37,1368 & 19,439 &, 242 &, 762 \\
pq7 & 37,0632 & 18,996 &, 398 &, 740 \\
pq8 & 37,1789 & 18,553 &, 504 &, 728 \\
pq9 & 37,1158 & 17,635 &, 589 &, 715 \\
pq10 & 37,2632 & 17,728 &, 544 &, 720 \\
\hline
\end{tabular}

Sumber: Pengolahan Data SPSS 23,0

Berdasarkan hasil uji validitas, variabel Perceived Quality (X2), dapat dikatakan bahwa seluruh item valid dengan nilai $r$ hitung positif dan lebih besar dari nilai $r$ tabel menurut (Sugiyono, 2017) $=0.1698$. dengan titik signifikansi 0,05.

\section{Uji Reliabilitas Harga (X3)}

Reliability Statistics

\begin{tabular}{|r|r|}
\hline $\begin{array}{c}\text { Cronbach's } \\
\text { Alpha }\end{array}$ & N of ltems \\
\hline, 762 & 10 \\
\hline
\end{tabular}

Sumber: Pengolahan Data SPSS 23,0 
Berdasarkan hasil pengolahan data dengan SPSS 23, dapat disimpulkan bahwa hasil uji reliabilitas dari variabel harga (X3), dinyatakan reliabel karena nilai cronbach alpha 0,762>0,70 dan layak menjadi indikator.

\section{Uji Validitas Harga (X3)}

Item-Total Statistics

\begin{tabular}{|l|c|r|r|r|}
\hline & $\begin{array}{c}\text { Scale Mean } \\
\text { if Item } \\
\text { Deleted }\end{array}$ & $\begin{array}{c}\text { Scale } \\
\text { Variance if } \\
\text { Item Deleted }\end{array}$ & $\begin{array}{c}\text { Corrected } \\
\text { Item-Total } \\
\text { Correlation }\end{array}$ & $\begin{array}{c}\text { Cronbach's } \\
\text { Alpha if Item } \\
\text { Deleted }\end{array}$ \\
\hline hrg1 & 35,4632 & 18,017 &, 586 &, 718 \\
hrg2 & 35,3053 & 18,959 &, 557 &, 725 \\
hrg3 & 35,3263 & 19,860 &, 403 &, 745 \\
hrg4 & 35,3368 & 20,502 &, 235 &, 771 \\
hrg5 & 35,6211 & 20,174 &, 209 &, 782 \\
hrg6 & 35,2842 & 19,206 &, 464 &, 736 \\
hrg7 & 35,0421 & 18,743 &, 609 &, 718 \\
hrg8 & 34,9895 & 20,649 &, 400 &, 746 \\
hrg9 & 34,9789 & 20,574 &, 453 &, 742 \\
hrg10 & 35,1684 & 18,908 &, 506 &, 731 \\
\hline
\end{tabular}

\section{Sumber : Pengolahan Data SPSS 23,0}

Berdasarkan hasil uji validitas, variabel harga (X3), dapat dikatakan bahwa seluruh item valid dengan nilai $r$ hitung positif dan lebih besar dari nilai $r$ tabel menurut ( Sugiyono, 2017) $=0.1698$. dengan titik signifikansi 0,05.

\section{Uji Reliabilitas Keputusan Pembelian (Y)}

\section{Reliability Statistics}

\begin{tabular}{|r|r|}
\hline $\begin{array}{c}\text { Cronbach's } \\
\text { Alpha }\end{array}$ & $\begin{array}{c}\text { N of } \\
\text { Items }\end{array}$ \\
\hline, 777 & 10 \\
\hline
\end{tabular}

\section{Sumber: Pengolahan Data SPSS 23,0}

Berdasarkan hasil pengolahan data dengan SPSS 23, dapat disimpulkan bahwa hasil uji reliabilitas dari variabel keputusan pembelian $(\mathrm{Y})$, dinyatakan reliabel karena nilai cronbach alpha 0,777 >0,70 dan layak menjadi indikator. 


\section{Uji Validitas Keputusan Pembelian (Y)}

Item-Total Statistics

\begin{tabular}{|l|r|r|r|r|}
\hline & $\begin{array}{c}\text { Scale Mean } \\
\text { if Item } \\
\text { Deleted }\end{array}$ & $\begin{array}{c}\text { Scale Variance } \\
\text { if Item Deleted }\end{array}$ & $\begin{array}{c}\text { Corrected } \\
\text { Item-Total } \\
\text { Correlation }\end{array}$ & $\begin{array}{c}\text { Cronbach's } \\
\text { Alpha if Item } \\
\text { Deleted }\end{array}$ \\
\hline kp1 & 34,1158 & 25,550 &, 545 &, 747 \\
kp2 & 34,2316 & 26,542 &, 429 &, 760 \\
kp3 & 34,1895 & 24,602 &, 511 &, 749 \\
kp4 & 34,2211 & 26,514 &, 344 &, 770 \\
kp5 & 33,9158 & 26,035 &, 471 &, 755 \\
kp6 & 34,1158 & 25,423 &, 477 &, 754 \\
kp7 & 33,9789 & 25,744 &, 557 &, 747 \\
kp8 & 33,8737 & 26,941 &, 357 &, 768 \\
kp9 & 35,0211 & 24,446 &, 439 &, 760 \\
kp10 & 34,6211 & 24,195 &, 400 &, 769 \\
\hline
\end{tabular}

Sumber: Pengolahan Data SPSS 23,0

Berdasarkan hasil uji validitas, variabel keputusan pembelian (Y), dapat dikatakan bahwa seluruh item valid dengan nilai $r$ hitung positif dan lebih besar dari nilai $r$ tabel menurut $($ Sugiyono, 2017) $=0.1698$. dengan titik signifikansi 0,05.

\section{Uji Koefisien Determinasi $\left(\mathbf{R}^{2}\right)$ dan Korelasi}

Menurut ( Ghozali 2016, 95 ) Koefisien Determinasi $\left(\mathrm{R}^{2}\right)$ mengukur seberapa jauh kemampuan model dalam menerangkan variasi variabel dependen. Nilai koefisien determinasi adalah antara nol dan satu. Maka jika $\mathrm{R}^{2}$ yang kecil, berarti kemampuan variabel - variabel independen dalam menjelaskan variasi variabel dependen amat terbatas. Berikut ini adalah output SPSS dari hasil uji koefisien determinasi $\left(\mathrm{R}^{2}\right)$ terhadap variabel Brand Name (X1), Perceived Quality (X2), harga (X3) dan Keputusan Pembelian (Y).

\section{Uji Koefisien Determinasi $\left(R^{2}\right)$}

\begin{tabular}{|c|c|c|c|c|}
\hline \multicolumn{5}{|c|}{ Model Summary ${ }^{b}$} \\
\hline $\begin{array}{l}\text { Mode } \\
1\end{array}$ & $\mathrm{R}$ & $\begin{array}{c}\mathrm{R} \\
\text { Square }\end{array}$ & $\begin{array}{c}\text { Adjusted R } \\
\text { Square }\end{array}$ & $\begin{array}{l}\text { Std. Error of } \\
\text { the Estimate }\end{array}$ \\
\hline 1 & ,721 & ,520 &, 504 & 39112 \\
\hline
\end{tabular}

Sumber: Pengolahan Data SPSS 23,0 
Berdasarkan tabel diatas diketahui bahwa besarnya Adjusted $R$ Square adalah 50,4\%. Hal ini menunjukkan adanya pengaruh terhadap keputusan pembelian. Sedangkan sisanya 49,6\% dijelaskan oleh sebab - sebab yang lain diluar model.

\section{Uji Statistik F}

Berdasarkan hasil pengolahan data menggunakan SPSS 23,0 dapat ditampilkan dibawah ini :

ANOVAa $^{a}$

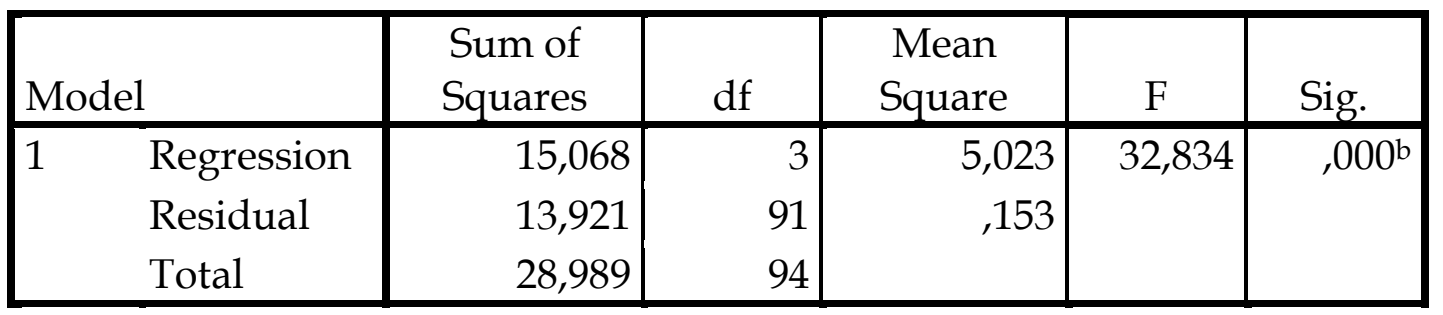

a. Dependent Variable: keputusan pembelian

b. Predictors: (Constant), harga, brand name, perceived quality

Sumber: Pengolahan Data SPSS 23,0

Berdasarkan uji ANOVA atau uji F menunjukkan bahwa variabel independen yaitu Brand Name, Perceived Quality dan Harga berpengaruh secara signifikan. Hal tersebut dapat dibuktikan dengan $\mathrm{F}$ hitung yaitu sebesar 32,834 lebih besar dari F tabel yaitu sebesar 2,70 menurut (Sugiyono, 2017). Dengan tingkat signifikan dibawah 0,05 yaitu sebesar 0,000. Sehingga penelitian ini boleh dilanjutkan serta Brand Name, Perceived Quality dan Harga bersama - sama berpengaruh terhadap Keputusan Pembelian.

\section{Uji Statistik $\mathbf{t}$}

Berikut adalah hasil pengolahan uji statistik $t$ terhadap variabel Brand Name (X1), Perceived Quality (X2), Harga (X3) dan Keputusan Pembelian (Y).

\begin{tabular}{|c|c|c|c|c|c|c|}
\hline \multicolumn{7}{|c|}{$\begin{array}{l}\text { Uji Statistik t } \\
\text { Coefficients }^{a}\end{array}$} \\
\hline \multirow{2}{*}{\multicolumn{2}{|c|}{ Model }} & \multicolumn{2}{|c|}{$\begin{array}{c}\text { Unstandardized } \\
\text { Coefficients }\end{array}$} & $\begin{array}{l}\text { Standardized } \\
\text { Coefficients }\end{array}$ & \multirow[b]{2}{*}{$t$} & \multirow[b]{2}{*}{ Sig. } \\
\hline & & B & $\begin{array}{l}\text { Std. } \\
\text { Error }\end{array}$ & Beta & & \\
\hline & (Constant) &,- 070 & ,395 & &,- 178 & ,859 \\
\hline & brand name & ,223 & 107 & ,204 & 2,085 & ,040 \\
\hline & $\begin{array}{l}\text { perceived } \\
\text { quality }\end{array}$ & ,335 & 119, & ,283 & 2,817 & ,006 \\
\hline & harga & ,401 & 111 & ,350 & 3,620 & ,000 \\
\hline
\end{tabular}

a. Dependent Variable: keputusan pembelian

Sumber: Pengolahan Data SPSS 23,0 
Berdasarkan tabel coefficient, kedua variabel memberikan pengaruh yang signifikan. Hal ini dapat dilihat dari angka signifikan yang didapat oleh variabel Brand Name sebesar 0,040, variabel Perceived Quality sebesar 0,006, dan variabel Harga sebesar 0,000. Ketiganya masih jauh di bawah 0,05. Sehingga dapat disimpulkan bahwa variabel Brand Name, Perceived Quality, dan Harga memberikan pengaruh pada Keputusan Pembelian.

\section{PEMBAHASAN}

Dari hasil pengolahan data diatas, bahwa Brand Name, Perceived Quality dan Harga berpengaruh positif terhadap Keputusan Pembelian bahan bakar jenis super dan Ha pun diterima. Dalam analisis data menunjukkan pengaruh Brand Name terhadap Keputusan Pembelian bahan bakar Shell jenis Super memiliki nilai t hitung sebesar 2,085 dan menunjukkan angka yang lebih besar daripada $t$ tabel sebesar 1.661 dengan nilai signifikan 0,040. Pengaruh Perceived Quality terhadap Keputusan Pembelian bahan bakar Shell jenis Super memiliki t hitung sebesar 2,817 dan menunjukkan angka yang lebih besar daripada $t$ tabel sebesar 1.661 dengan nilai signifikan 0,006. Pengaruh Harga terhadap Keputusan Pembelian bahan bakar Shell jenis Super memiliki t hitung sebesar 3,620 dan menunjukkan angka yang lebih besar daripada $t$ tabel sebesar 1.661 dengan nilai signifikan 0.000. Ini membuktikan bahwa ketiga variabel bebas memiliki pengaruh positif dan nilai signifikan dibawah 0,05. Untuk membuktikan hipotesis 1 dilihat dari nilai Korelasi Brand Name terhadap Keputusan Pembelian sebesar 0,582. Membuktikan hipotesis 2 dilihat dari nilai Korelasi Perceived Quality terhadap Keputusan Pembelian sebesar 0,623. Dan membuktikan hipotesis 3 dilihat dari nilai nilai Korelasi Harga terhadap Keputusan Pembelian sebesar 0,641. Berdasarkan uji ANOVA atau uji F menunjukkan bahwa variabel independen yaitu Brand Name, Perceived Quality dan Harga berpengaruh secara signifikan. Hal tersebut dapat dibuktikan dengan $\mathrm{F}$ hitung yaitu sebesar 32,834. Besar nilai Adjusted R Square adalah 50,4\%. Hal ini menunjukkan adanya pengaruh terhadap keputusan pembelian. Sedangkan sisanya 49,6\% dijelaskan oleh sebab - sebab yang lain diluar model. Dalam uji heterokedastisitas, titik - titik menyebar secara acak, sehingga tidak terjadi heterokedastisitas. Dalam uji normalitas juga titik - titik di sekitar garis diagonal dan mengikuti arah garis diagonal, sehingga dapat dikatakan bahwa model regresi memenuhi asumsi normalitas.

\section{KESIMPULAN}

Berdasarkan hasil analisis dan pembahasan pada bab sebelumnya tentang "Pengaruh Brand Name, Perceived Quality, dan Harga terhadap Keputusan Pembelian bahan bakar Shell jenis Super, studi kausalitas pada pengguna motor produksi masal dapat disimpulkan beberapa hal sebagai berikut:

1. Hasil perhitungan koefisien korelasi untuk Brand Name adalah sebesar 0,582 dengan tingkat signifikan 0,000. Hal ini menunjukkan bahwa variabel Brand Name berpengaruh pada Keputusan Pembelian.

2. Hasil perhitungan koefisien korelasi untuk Perceived Quality adalah sebesar 0,623 dengan tingkat signifikan 0,000. Hal ini menunjukkan bahwa variabel Perceived Quality berpengaruh pada Keputusan Pembelian. 
3. Hasil perhitungan koefisien korelasi untuk Harga adalah sebesar 0,641 dengan tingkat signifikan 0,000. Hal ini menunjukkan bahwa variabel Harga berpengaruh pada Keputusan Pembelian.

4. Berdasarkan hasil penelitian, didapat $\mathrm{F}$ hitung yaitu sebesar 32,834 lebih besar dari $\mathrm{F}$ tabel yaitu sebesar 2,70 dengan tingkat signifikan dibawah 0,05 yaitu sebesar 0,000. Dengan demikian Ho ditolak dan Ha diterima, artinya terdapat pengaruh linier antara Brand Name, Perceived Quality, Harga terhadap Keputusan Pembelian.

5. Pengaruh Brand Name terhadap Keputusan Pembelian terbukti berpengaruh positif dilihat dari hasil $\mathrm{t}$ hitung $>\mathrm{t}$ tabel yaitu sebesar 2,085 $>1,661$ dengan nilai signifikan $<0,05$ yaitu sebesar 0,040.

6. Pengaruh Perceived Quality terhadap Keputusan Pembelian terbukti berpengaruh positif dilihat dari hasil $\mathrm{t}$ hitung $>\mathrm{t}$ tabel yaitu sebesar 2,817 $>1,661$ dengan nilai signifikan $<0,05$ yaitu sebesar 0,006.

7. Pengaruh Harga terhadap Keputusan Pembelian terbukti berpengaruh positif dilihat dari hasil $\mathrm{t}$ hitung $>\mathrm{t}$ tabel yaitu sebesar 3,620 $>1,661$ dengan nilai signifikan $<0,05$ yaitu sebesar 0,000 .

8. Dari hasil penelitian yang dilakukan, terbentuk persamaan regresi linear yaitu : $Y$ $=-0,70+0,223 X 1+0,335 X 2+0,401 X 3$.

9. Mayoritas responden yang menjawab kuisioner berjenis kelamin pria, berumur 20 - 29 tahun, berprofesi pegawai swasta, berpendidikan terakhir SMA / SMK dan pengeluaran biaya hidup rata - rata per bulan sekitar 1 juta - 2 juta.

\section{DAFTAR PUSTAKA}

Aaker, D. (2014). Aaker on Branding. New York: Morgan James Publishing.

Athoillah, D. A. (2010). Dasar Dasar Manajemen. Bandung: CV Pustaka Setia.

Badrudin, M. Ag, D. (2013). Dasar - Dasar Manajemen. Bandung: Alfabeta.

Borrington, K., \& Stimpson, P. (2006). IGCSE Business Studies. London: Hodder Education.

Elliott, G., Rundle-Thiele, S., \& Waller, d. (2012). Marketing Second Edition. Australia: Wiley.

Evans, M., Jamal, A., \& Foxall, G. (2009). Consumer Behaviour Second Edition. England: Wiley.

Ferdinan, Comaeni Enril, \& Nugraheni, R. (2013). ( Studi Pada Pembeli - Pengguna Sepeda Motor Suzuki di Kota Solo ), 2, 1-8.

Feriyanto, A., \& Triana, E. S. (2015). Pengantar Manajemen 3 in 1. Kebumen: Mediatera.

Ghozali, I. (2016). Aplikasi Analisis Multivariete dengan Program IBM SPSS 23. Semarang: Badan Penerbit Universitas Diponegoro.

Ho, R. (2006). Handbook of Univariate and Multivariate Data Analysis and Interpretation with SPSS. Chapman \& Hall: Boca Raton.

Krisno, D., \& Samuel, H. (2013). Pengaruh Perceived Quality , Perceived Sacrifice dan Perceived Value terhadap Customer Satisfaction di Informa Innovative Furnishing Pakuwon City Surabaya. Manajemen Pemasaran, 1(1), 1-12.

Kotler, P., \& Keller, K. L. (2016). Marketing Management. England: Pearson. 
Lestari, M. S., Komariah, A., Studi, P., Industri, T., Teknik, F., Veteran, U., \& Nusantara, B. (2016). superioritas atau keunggulan (Zeithaml, 1988 ). Menurut Cho dan Pucik ( 2005 ) kualitas merupakan ambang batas dinamis yang harus dipenuhi oleh perusahaan untuk memuaskan, (November), 182186.

Ma'arif, N. N. (2008). The Power of Marketing. Jakarta: Salemba empat.

Neuman, W. L. (2014). Social Research Methods : Qualitative and Quantitative Approach. Harlow: Pearson.

Nurtjahjant, H. (2012). Hubungan Antara Persepsi Terhadap Harga Dan Kualitas Produk Dengan Minat Membeli Produk Fashion Onlineshop Di Facebook Pada Mahasiswa Politeknik Semarang, 11, 8.

Pavlickova, H., Varese, F., Smith, A., Myin-Germeys, I., Turnbull, O. H., Emsley, R., \& Bentall, R. P. (2013). The Dynamics of Mood and Coping in Bipolar Disorder: Longitudinal Investigations of the Inter-Relationship between Affect, Self-Esteem and Response Styles. PLoS ONE, 8(4). https:// doi.org/10.1371/journal.pone.0062514

Sangadji, E. M., \& Dr.Sopiah. (2013). Perilaku Konsumen . Yogyakarta: CV Andi Offset.

Solomon, M. R. (2015). Consumer Behaviour Buying, Having, and Being. Harlow: Pearson.

Sugiyono, P. D. (2017). Metode Penelitian Bisnis. Bandung: Alfabeta.

Tjiptono, F. (2008). Service, Quality and Satisfaction. New York: Taylor \& Francis Inc.

Wankhade, L., \& Dabade, b. (2010). Quality Uncertainty and Perception. Berlin: Physica Verlag.

https:/ / books.google.co.id/books?id=508DCKbjO58C\&lpg=PA27\&dq=perceived $\% 2$ 0quality\&pg $=\mathrm{PR} 11 \# \mathrm{v}=$ onepage $\& \mathrm{q}=$ perceived $\% 20$ quality $\& \mathrm{f}=$ false

https://books.google.co.id/books?id=Bu3YAgAAQBAJ\&lpg=PA48\&dq=perceived

\%20quality \%20david \%20aaker\&pg=PR6\#v=onepage\&q=perceived $\% 20$ qualit

$\mathrm{y} \% 20$ david $\% 20$ aaker $\& \mathrm{f}=$ false

https://www.shell.co.id/in_id/tentang-kami/what-we-do.html http://junaidichaniago.wordpress.com 